\title{
MOLECULAR EVIDENCE FOR EXTRA-PAIR PATERNITY AND INTRASPECIFIC BROOD PARASITISM IN THE BLACK-HEADED GULL
}

\section{RADKA LEŽALOVÁ-PIÁLKOVÁ ${ }^{1,2}$}

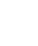

${ }^{1}$ Department of Zoology, Faculty of Sciences, University of South Bohemia, Branišovská 31, 37005 České Budějovice, Czech Republic.

${ }^{2}$ Institute of Vertebrate Biology Academy of Sciences of the Czech Republic, Květná 8, 60365 Brno, Czech Republic.

(1)

3

corresponding author: Radka Ležalová-Piálková

e-mail: Radka.Lezalova@prf.jcu.cz

telephone: +420387772238

(1)

(1)

9

Running headline: EPP and ISBP in the Black-headed Gull

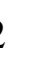

3

4




\section{Abstract}

Social monogamy is common among birds, while genetic monogamy is supposed to be rare. I investigated the genetic mating system of the Black-headed Gull Larus ridibundus, where, as in seabirds and most other long-lived and socially monogamous birds, extrapair paternity (EPP) is typically rather infrequent. Parentage was determined using six microsatellite markers for 79 chicks from 30 broods. In this study population, I found evidence of allelic inconsistencies between putative parents and chicks in $43 \%$ of nests, resulting from both EPP and intraspecific brood parasitism (ISBP). Extra-pair paternity was detected in $33 \%(10 / 30)$ of broods, and $20 \%(16 / 79)$ of all nestlings were sired by extra-pair males. Furthermore, $9 \%(7 / 79)$ of chicks out of 5 nests $(17 \%)$ were not the offspring of either member of the pair, indicating ISBP. These findings reveal a moderate rate of ISBP and a high rate of EPP compared with other related species, and shows that Black-headed Gulls successfully participate in extra-pair copulations.

Key words Black-headed Gull, genetic mating system, extra-pair paternity, intraspecific brood parasitism, Larus ridibundus

\section{Zusammenfassung}

Molekularer Nachweis von Fremdvaterschaft und intraspezifischem Brutparasitismus bei der Lachmö we Larus ridibundus

Soziale Monogamie ist bei Vögeln weitverbreitet, während genetische Monogamie vermutlich selten ist. Ich habe das genetische Paarungssystem der Lachmöwe Larus ridibundus untersucht, bei der, wie bei Seevögeln und den meisten anderen langlebigen und sozial monogamen Vögeln, Fremdvaterschaft (EPP) normalerweise eher selten ist. Die Elternschaft wurde mittels sechs Mikrosatellitenmarkern für 79 Küken aus 30 Bruten ermittelt. In der untersuchten Population fand ich Belege für Allelinkonsistenzen zwischen Putativeltern und Küken in $43 \%$ der Nester, was sowohl auf EPP als auch auf intraspezifischen Brutparasitismus (ISBP) zurückzuführen war. Fremdvaterschaft wurde in $33 \%$ (10/30) der Bruten nachgewiesen, und $20 \%$ (16/79) aller Nestlinge wurden von Fremdvätern gezeugt. Außerdem stammten $9 \%$ (7/79) der Küken aus fünf Nestern (17\%) weder von der Mutter noch vom Vater ab, was auf ISBP hindeutet. Diese Ergebnisse lassen eine im Vergleich zu 
61 anderen verwandten Arten mittlere ISBP-Rate und eine hohe EPP-Rate erkennen und zeigen,

62 dass Lachmöwen erfolgreich Kopulationen außerhalb des Paarbundes eingehen.

63

64

65

66

67

68

69

70

71

72

73

74

75

76

77

78

79

80

81

83

84

86

87

\section{Introduction}

The application of molecular techniques to avian mating systems has revealed striking variation in the incidence of alternative reproductive strategies such as extra-pair paternity (EPP) and intraspecific brood parasitism (ISBP) (Birkhead and Møller 1992; Petrie and Kempenaers 1998; Arnold and Owens 2002). Even though many hypotheses have been proposed to explain this variation (Petrie and Kempenaers 1998; Møller and Ninni 1998; Arnold and Owens 2002; Griffith et al. 2002; Westneat and Stewart 2003; Neudorf 2004), there is still inconsistency in the results. The strongest correlation with EPP was found phylogenetic. High EPP rates are associated with high rates of adult mortality and reduced parental care, while high ISBP rates are associated with high fecundity rates (Arnold and Owens 2002; Bennett and Owens 2002). Variation at the population or individual level is more likely to be based on differences in current ecological and genetic factors (Petrie and Kempenaers 1998). Of ecological factors, breeding density may be an important factor at the species level (Westneat and Sherman 
1997). Colonially nesting species are predicted to have high EPP rates because proximity to potential partners is high (Møller and Birkhead 1993).

The Black-headed Gull, like other gulls, is a long lived, colonially breeding species with high adult survivorship (Cramp 1983). The standard clutch size of this species is three eggs. Both females and males participate in parental care throughout incubation and chick-rearing, which leads to social monogamy in this species (Cramp 1983). Given these traits, a low frequency of EPP and ISBP could be expected.

The major goal of this study was to describe the rates of extra-pair parentage and intraspecific parasitism in the Black-headed Gull.

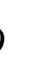

(1)

(1) 
119 within a $1.6 \mathrm{~cm}$ mesh wire circle about $1 \mathrm{~m}$ in diameter and $40 \mathrm{~cm}$ high. This fence

120 prevented the escape of young chicks but allowed adults to access the nests.

121 On the first day after hatching, approximately $25 \mu \mathrm{l}$ of blood was obtained from

122 the brachial or tarsal vein of chicks and mixed with $150 \mu$ of storage buffer (0.5M EDTA).

123 Samples of embryos were collected from unhatched eggs. All samples were kept at $12420^{\circ} \mathrm{C}$ until DNA extraction.

\section{Molecular determination of sex}

The sex of social parents was determined by a polymerase chain reaction that

128 amplifies an intron of the CHD1 genes on the sex chromosomes (Griffiths et al. 1998).

129 Genomic DNA was isolated from $10 \mu \mathrm{l}$ of blood sample using the DNA Lego Kit (Top Bio)

130 following the manufacturer's protocol. The avian sexing primers $2550 \mathrm{~F}$ and $2718 \mathrm{R}$

131 (Fridolfsson and Ellegren 1999) were used in $10 \mu \mathrm{l} \mathrm{PCR}$ reactions. The PCR conditions

132 were as follows: $1 \mu$ l of $10 \mathrm{X}$ PCR buffer (TaKaRa), $2 \mu \mathrm{M}$ of each dNTP, 2.5 pmol of each

133 primer and $0.5 \mathrm{U}$ of Taq polymerase (TaKaRa). About $150 \mathrm{ng}$ of genomic DNA was used

134 as template. PCR was performed according to Griffiths et al. (1998) in a T3 Biometra

135 thermal cycler. The products were separated by electrophoresis for 45-60 min at 7-10

$136 \mathrm{~V} / \mathrm{cm}$ using a $3 \%$ agarose gel stained with ethidium bromide.

\section{Parentage analyses}

139 Microsatellite typing was used to reveal the genetic relationships between parents and 140 young. Parentage was analysed using 6 polymorphic dinucleotide microsatellite loci (RBG

141 13, RBG 18, RBG 20, RBG 27, RBG 28, RBG 29) originally developed for the Red-billed

142 Gull Larus novaehollandiae scopulinus (Given et al. 2002). These six loci exhibited little

143 or no evidence of null alleles and showed sufficient levels of polymorphism (mean 144 heterozygosity $=0.77$, mean number of alleles $=11.3$ ), making them suitable for 145 paternity assessment in this species (combined exclusion probability: first parent $=0.98$, 146 second parent $=0.998)($ Table.1).

147 Genomic DNA was extracted from $10 \mu \mathrm{l}$ of blood sample or from 25-35 mg of 
148 embryo tissue (depending on type of tissue) from unhatched eggs. The $10 \mu \mathrm{l} \mathrm{PCR}$

149 reactions consisted of about $100 \mathrm{ng}$ of template DNA, 0.4 units of Taq Polymerase

150 (TaKaRa), $1 \mu$ of 10x PCR buffer (TaKaRa), $2.5 \mu \mathrm{M}$ dNTPs and 2.5 pmol of each primer.

151 The forward primer was fluorescently labelled. The PCR conditions followed the protocol

152 described by Given et al. (2002).

153 Amplification products were run on an ABI Prism 3100 automatic sequencer, and

154 Gene Mapper software (Applied Biosystems Inc) was used to size the alleles. The number 155 of alleles, observed and expected heterozygosity, parentage exclusion probability for the 156 first and second parents, and theoretical frequency of null alleles for each locus were 157 estimated with CERVUS 3.0 .3 software (Kalinowski et al. 2007) (Table. 1). Allele 158 frequencies were used to calculate the cumulative probability of resemblance $P_{R C u m}$ for 159 specific parent-offspring cases where ambiguous mismatches occurred (Ibarguchi et al. 160 2004).

Results

I assessed paternity for 79 chicks and 60 adults from 30 broods. Offspring that possessed a microsatellite allele that did not match the putative father at two or more loci were considered extra-pair young (EPY), and offspring that did not share an allele with either of their social parents were considered to be a case of intraspecific brood parasitism. In 17 out of 30 sampled nests (57\%), I found no case of allelic mismatch between the offspring and their putative parents. Thus, all social parents were true

171 genetic parents in these nests. However, in 13/30 (43\%) nests, allelic inconsistencies

172 between putative parents and chicks were detected, resulting from both EPP and ISBP.

173 More specifically, in $10 / 30$ (33 \%) nests I found that $17 / 79(21.5 \% ; 95 \%$ c.i.: 0.13 -

174 0.32) chicks shared the same allele at each locus with their mother, but were 175 mismatched with the social father in at least two loci (Table.2). The number of 176 mismatching loci in extra-pair chicks ranged from two to five loci (Table.3). In three 
177 cases, where the chick and its putative father differed only in two loci, I estimated the

178 likelihood that mismatched loci were caused by mutation. Cumulative probabilities of 179 resemblance $\left(P_{\text {Rcum }}\right.$; Ibarguchi et al. 2004) were calculated for these three chicks,

180 excluding loci with the mismatched alleles. In two cases, the probabilities of sharing

181 alleles by chance were so high $\left(0.2 \times 10^{-3}\right.$ and $\left.1.3 \times 10^{-3}\right)$ that mismatches due to mutation 182 could be ruled out. In the third case, the cumulative probability of resemblance was 183 much lower $\left(5 \times 10^{-6}\right)$, suggesting that this was a case of mutation and the chick could be 184 reassigned as legitimate. I considered the remaining $16 / 79$ (20\%; 95\% c.i.: 0.12-0.31) 185 chicks to be extra-pair, since in all cases social mothers were also true genetic mothers. 186 Moreover, in two of the ten nests with EPY and in three other nests I found chicks 187 which did not match either of their social parents. Altogether $7 / 79$ (9\%; $95 \%$ c.i.: $0.04-$ $1880.17)$ chicks out of $5 / 30(17 \%)$ nests were considered to result from intraspecific brood parasitism (Table.2). The frequency of mismatching loci in these parasitic chicks ranged

190 from 3 to 6 loci (Table.3).

191 Finally, in another five chicks I detected differences between chicks and parents at 192 a single locus; in four cases chicks differed from their social father and in one case the 193 chick mismatched at one locus with their mother. The cumulative probabilities of 194 resemblance were calculated for these five chicks, excluding loci with the mismatched 195 alleles. In four of five cases, probabilities of sharing alleles by chance were so low ( $4.08 \mathrm{x}$ $19610^{-6}$ to $7.01 \times 10^{-7}$ ) that mutation is the most probable reason for the mismatches. In the 197 last case, the probability of sharing alleles was higher $\left(1 \times 10^{-2}\right)$ due to the male and 198 chick sharing common alleles (Table.3). All those five chicks were considered as within 199 pair offspring.

\section{Discussion}


EPP is relatively high in comparison to related species and other colonially breeding seabirds (e.g. Mauck et al. 1995, Gilbert et al. 1998, Lorentsen et al. 2000, Griggio et al. 2004). Previously measured variation in EPF rates for Laridae species has been low, ranging from zero in the Western Gull (Larus occidentalis;Gilbert et al. 1998), Blacklegged Kittiwake (Rissa tridactyla; Helfenstein et al. 2004), Common Tern (Sterna 211 hirundo; Griggio et al. 2004) and Little Auk (Alle alle; Lifjeld et al. 2005), to $8.3 \%$ in 212 Common Gull (Larus canus; Bukacinska et al. 1998). These findings are in line with the 213 prediction of low EPP rates in species with a long reproductive lifespan, such as seabirds. In contrast, my data suggest that Black-headed Gulls have an unexpectedly high rate of EPP. Extra-pair paternity could arise by two means, either as the result of extra216 pair copulations (EPC), or rapid mate-switching (Birkhead and Møller, 1992, Martins et al. 2002). In gulls, EPCs are common (Mills 1994, Bukacinska et al. 1998). In Black-headed 218 Gulls, copulation activity has not yet been studied in detail; Frantová (2007) found a low 219 frequency of forced copulations (1.8\%), but did not distinguish between within-pair and 220 unforced extra-pair copulations.

I collected no behavioural data on mate-switching, so that I can not exclude the possibility that the two nests where all three chicks were found to be sired by other than the social father (Table.2) could be cases of mate-switching or, alternatively, cases of putative father infertility. The replacement of a mate might happen rapidly due to a large supply of potential mates and strong competition for mates during the early stage of breeding. In the remaining 8 nests, one (5 nests) or two (3 nests) EPYs were detected, probably resulting from successful EPCs (Table.2). However, to unequivocally explain this high rate of EPP, other, especially behavioural studies will be necessary. Furthermore,

229 the accuracy of the estimate could be affected by used sample size (Griffith et al. 2002).

230 Griffith et al. (2002) suggest that approximately 200 offspring is a reasonable sample 231 size limiting the magnitude of error around the estimate. The magnitude of error around 232 my estimate of EPP level in studied population is $19 \%$, which suggest that further 233 sampling would increased the accuracy of the estimate. 
235 strategy of gulls. In five (17\%) out of 30 sampled nests, at least one chick was found

236 that did not match either of their social parents. This rate of ISBP should not be affected 237 by possible chick adoption, since the studied nests were enclosed with mesh wire and 238 chicks were sampled within a couple of hours after hatching. Multiple parentage in these 239 clutches most probably occurred through nest parasitism. The possibility that some of the 240 mixed clutches represented female-female pairs or quasi-parasitism can be excluded, 241 since the social parents trapped at each nest were always a male and female, and neither 242 of them matched potentially parasitic chicks.

243 Among 61 species of gulls, intraspecific parasitism has been documented in 244 another four species (Larus argentatus, L. canus, L. delawarensis and L. minutus; in 245 Yom-Tov 2001 and Duda et al. 2008) as well as in the Black-headed Gull (Duda et al. 246 2008, Ležalová-Piálková and Honza 2008). Duda et al. (2008) revealed the maternity in 247 a population of Black-headed Gulls in Poland by protein fingerprinting, and found multiple 248 maternity in $34 \%$ of nests with $>1$ egg. These results are much higher then those 249 obtained from a previous study of ISBP based on the regular monitoring of nests in the 250 same Black-headed Gull population as the current study, (Ležalová-Piálková and Honza 251 2008). In this previous analysis, we found a parasitism rate of $10 \%$, which now seems to 252 be an underestimation. These studies allow an interesting comparison between three 253 different methodological approaches to the question of ISBP, showing that a molecular 254 approach is essential for finding the real frequencies of ISBP in birds (Grønstøl et al. 255 2006).

\section{Acknowledgments}

This research was funded by GAJU 51/2003/P-BF and MSM 6007665801 grants 261 and was also supported by GAČR 206/05/H012. This study was carried out under 262 permission $2 \mathrm{KCDW} 28 / 0 / 2003$ and in accordance with the laws and ethical guidelines of 
263 the Czech Republic. I thank M. Honza for field assistance, J. Bryja for advice in the lab,

264 D. Hardekopf for English corrections and anonymous referees for valuable comments on 265 the manuscript.

\section{References}

Arnold KE, Owens IPF (2002) Extra-pair paternity and egg dumping in birds: life history, 271 parental care and the risk of retaliation. Proc R Soc Lond B 269:1263-1269

272 Bennett PM, Owens IPF (2002) Evolutionary Ecology of Birds Oxford: Oxford University 273 Press, Oxford

274 Birkhead TR, Møller AP (1992) Sperm competition and sexual selection. Academic Press, 275 London

276 Bukacińska M, Bukaciński D, Epplen JT, Sauer KP, Lubjuhn T (1998) Low frequency of 277 extra-pair paternity in Common Gulls (Larus canus) as revealed by DNA fingerprinting. J 278 Ornithol 139:413-420

279 Cramp S (1983) The birds of the western palearctic. vol 3. Oxford University Press, New 280 York

281 Duda N, Chetnicky W, Waldeck P, Andersson M (2008) Multiple maternity in black282 headed gull Larus ridibundus clutches as revealed by protein fingerprinting. J Avian Biol $283 \quad 39: 116-119$

284 Frantová D (2007) Mating activity of the black headed-gull (Larus ridibundus). Sylvia $285 \quad 43: 51-60$

286 Fridolfsson AK, Ellegren H (1999) A simple and universal method for molecular sexing of 287 non-ratite birds. J Avian Biol 30:116-121

288 Gilbert L, Burke T, Krupa A (1998) No evidence of extra-pair paternity in the western 289 gull. Mol Ecol 7:1549-1552

290 Given AD, Mills JA, Baker AJ (2002) Isolation of polymorphic microsatellite loci from the 291 red-billed gull (Larus novaehollandiae scopulinus) and amplification in related species. 
Mol Ecol Notes 2:416-418

293 Griffith SC, Owens IPF, Thuman K (2002) Extra pair paternity in birds: a review of 294 interspecific variation and adaptive function. Mol Ecol 11:2195-2212

295 Griffiths R, Double MC, Orr K, Dawson RJG (1998) A DNA test to sex most birds. Mol Ecol $296 \quad 7: 1071-1075$

297 Griggio M, Matessi M, Marin G (2004) No evidence of extra-pair paternity in a colonial 298 seabird, the common tern (Sterna hirundo). Ital J Zool 71:219-222

299 Grønstøl G, Blomqvist D, Wagner RH (2006) The importance of genetic evidence for 300 identifying intra-specific brood parasitism. J Avian Biol 37:197-199.

301 Helfenstein F, Tirard C, Danchin E, Wagner RH (2004) Low frequency of extra-pair 302 paternity and high frequency of adoption in black-legged kittiwakes. Condor 106:149-155 303 Huyvaert KP, Anderson DJ, Jones TC, Duan W, Parker PG (2000) Extra-pair paternity in 304 waved albatrosses. Mol Ecol 9:1415-1419

305 Ibarguchi G, Gissing GJ, Gaston AJ, Boag PT, Friesen VL (2004) Male-biased mutation 306 rates and the overestimation of extrapair paternity: Problem, solution, and illustration 307 using thick-billed murres (Uria lomvia, Alcidae). J Hered 95:209-216

308 Kalinowski ST, Taper ML, Marshall TC (2007) Revising how the computer program 309 CERVUS accommodates genotyping error increases success in paternity assignment. Mol 310 Ecol 16: 1099-1006

311 Ležalová-Piálková R, Honza M, (2008) Responses of black-headed gulls Larus ridibundus 312 to conspecific brood parasitism. J Ornithol 149:415-421

313 Lifjeld JT, Harding AMA, Mehlum F, Øigarden T (2005) No evidence of extra-pair paternity 314 in the little auk Alle alle. J Avian Biol 36:484-487

315 Lorentsen S, Amundsen T, Anthonisen K, Lifjeld JT (2000) Molecular evidence for 316 extrapair paternity and female-female pairs in antarctic petrels. Auk 117:1042-1047

317 Martins TLF, Blakey JK, Wright J (2002) Low incidence of extra-pair paternity in the 318 colonially nesting common swift Apus apus. J Avian Biol 33:441-446

319 Mauck RA, Waite TA, Parker PG (1995) Monogamy in Leach's storm-petrel: DNA320 fingerprinting evidence. Auk 112:473-482 
321 Mills JA (1994) Extra-pair copulations in the red-billed gull-females with high quality,

322 attentive males resist. Behaviour 128:41-64

323 Møller AP, Birkhead TR (1993) Cuckoldry and sociality: a comparative study of birds. Am

324 Nat 142:118-131

325 Møller AP, Ninni P (1998) Sperm competition and sexual selection: a meta-analysis of

326 paternity studies of birds. Behav Ecol Sociobiol 43:345-358

327 Neudorf DLH (2004) Extra pair paternity in birds: understanding variation among 328 species. Auk 121:302-307

329 Petrie M, Kempenaers B (1998) Extra-pair paternity in birds: explaining variation

330 between species and populations. Trends Ecol Evol 13:52-58

331 Westneat DF, Sherman PW (1997) Density and extra-pair fertilization in birds: a 332 comparative study. Behav Ecol Sociobiol 41:205-215

333 Westneat DF, Stewart IRK (2003) Extra pair paternity in birds: Causes, Correlates and

334 Conflict. Ann Rev Ecol Evol Syst 34: 365-396

335 Yom-Tov Y (2001) An update list and some comments on the occurrence of intraspecific

336 nest parasitism in birds. Ibis 143:133 - 143

Table 1

341 Table.1 Polymorphism data for six microsatellite markers in the Black-headed Gull.

342 Values are based on the genotypes of 60 parents and calculated using CERVUS 3.0.3. $k$ -

343 the number of alleles, size (bp)- range of allele size in base-pairs, He - expected 344 heterozygosity, Ho - observed heterozygosity, $F_{\text {null }}$ - estimated frequency of the null 345 allele, $N E-1 P$ - non-exclusion probability for the first parent, $N E-2 P$ - non-exclusion 346 probability for the second parent.

\begin{tabular}{|c|c|c|c|c|c|c|c|}
\hline Locus & $k$ & size (bp) & $\mathrm{He}$ & Ho & Fnull & $N E-1 P$ & $N E-2 P$ \\
\hline RBG 13 & & $205-223$ & 0.82 & 0.86 & 0.02 & 0.54 & 0.36 \\
\hline
\end{tabular}




\begin{tabular}{cccccccc}
\hline RBG 18 & 6 & $170-180$ & 0.39 & 0.35 & 0.09 & 0.93 & 0.8 \\
RBG20 & 16 & $169-203$ & 0.92 & 0.9 & 0.01 & 0.29 & 0.17 \\
RBG 27 & 21 & $185-235$ & 0.91 & 0.89 & 0 & 0.33 & 0.2 \\
RBG 28 & 7 & $159-173$ & 0.76 & 0.75 & 0 & 0.64 & 0.46 \\
347 & 9 & $125-141$ & 0.81 & 0.9 & 0.06 & 0.56 & 0.38 \\
\hline
\end{tabular}

Table 2

Table.2 Distribution of chicks with extra-pair paternity (EPP) and parasitic chicks (ISBP) 358 across the nests. $\mathrm{n}=$ number of analysed nests.

\begin{tabular}{llc}
\hline $\begin{array}{c}\text { No. of chicks with extra- } \\
\text { pair parentage in nest }\end{array}$ & $\begin{array}{c}\text { Total } \\
\text { (chick/nests) }\end{array}$ & $\begin{array}{l}\mathrm{n} \\
\end{array}$
\end{tabular}

No. of nests with determined EPP

6

2

2

$16 / 10$

\section{ISBP}

4

1

7/5 30

360 
366 Table.3 Frequency of chicks with different number of mismatched loci. PR ${ }_{\text {cum }}$ -

367 cumulative probability of resemblance of sharing alleles by chance for parent-offspring

368 cases with low number of mismatching loci, nd - not defined.

\begin{tabular}{ccll}
\hline No. of mismatched loci & No. of chicks & $\mathrm{PR}_{\text {cum }}$ & Classified as \\
\hline 1 & 5 & $1 \times 10^{-2}$ to $7.01 \times 10^{-7}$ & true parentage \\
2 & 1 & $5 \times 10^{-6}$ & true parentage \\
2 & 2 & $0.2 \times 10^{-3}$ and $1.3 \times 10^{-3}$ & EPP \\
$>3(\max .5)$ & 14 & nd & EPP \\
$>3(\max .6)$ & 7 & nd & ISBP \\
\hline
\end{tabular}

369 